\title{
Better to hesitate at the threshold of compulsion: PKU testing and the concept of family autonomy in Eire
}

\section{G Laurie}

Irish Supreme Court upholds paramountcy of parental right to determine a child's best interests at the expense of the rights of children themselves

$\mathrm{C}$ an a court force on parents who are careful and conscientious a view of their child's welfare which is rational, but quite contrary to the parents sincerely held but non-rational beliefs? The Supreme Court of Ireland has recently held that it cannot do so, and that the Irish Constitution requires that the right of the family to determine its own direction must be respected except in the most narrow of circumstances, such as an immediate threat to the life of the child or risk of serious injury. The ruling leaves the assessment of a child's best interests to the wide discretion of parents, but at the same time fails to offer a means to resolve potential conflicts between the rights of the family and the rights of the child.

\section{FACTS OF THE CASE}

In North Western Health Board $\mathrm{V}$ W $(\mathrm{H})^{1}$ an action was brought by a local health board against the parents of 14 month old Paul, seeking a declaration that their refusal to submit their son to the heel prick test for phenylketonuria (PKU) was a failure to vindicate their son's rights and that it would be lawful to proceed without parental consent. Phenylketonuria is a metabolic condition which can lead to severe and untreatable mental impairment if not detected in its early stages, but a simple variation in diet can stave off this outcome. While Paul's parents did not doubt the veracity of this medical opinion, nor indeed the importance of the test, they refused to subject their son to the invasive heel prick, offering instead samples of urine or hair, such that the test could be carried out by non-invasive means. These means, however, are considerably less sensitive and all Western nations that have adopted a policy of screening neonates for PKU employ the blood test. And, while the parents had informally suggested that there were religious reasons for their refusal, this argument was not put before the courts, thus the matter was one of whether the clear objective benefit to the child could override the parents' simple, and yet unsubstantiated, wish that the test not be carried out.

This case raises profound questions about the legal relationship between parents and children in Ireland, the powers and duties of the state to act for the benefit of children, and the resolution of potential conflicts between parental and state obligations towards children and their health. The plaintiffs (the health board) presented the case as a straightforward matter of the paramountcy of the welfare of the child, but the Supreme Court correctly pointed out that this ignored the weight that the Irish Constitution gives to the views and authority of parents in bringing up their children. This proved to be the determining issue in the case.

"The family" is protected by the Irish Constitution as the "natural, primary, and fundamental unit group in society", ${ }^{\prime 2}$ and the family has an authority which the constitution recognises as superior even to that of the state itself. As a consequence, the state guarantees to protect the family as an autonomous moral institution and to guard against arbitrary interference in its decision making processes. This, in turn, has been interpreted to mean that parents have the primary responsibility for the upbringing and welfare of their children and that state intervention is only permissible in exceptional circumstances. All of this was upheld as a matter of constitutional principle in the instant case. And, while the court found it impossible to articulate all circumstances in which state interference might be justified, the majority opined that at a minimum there must be an immediate and fundamental threat to a child's capacity to function as a human person (either physically, morally, or socially), deriving from exceptional dereliction of duty on the part of parents. This was not thought to be the case here for the child was neither in a position of immediate threat, nor was there any suggestion that the parents were unfit to act as such: "a conscientious disagreement with the public health authorities does not constitute a failure in duty or an exceptional case justifying intervention".

While all judges agreed that the essence of the test to be applied was the best interests of the child, the majority considered that the presumption arising from the constitution is that the welfare of the child is to be found in a determination of those interests by the family exercising its authority as such, and that this can only be rebutted by countervailing constitutional considerations such as an immediate threat to life.

A further concern for the court was that an order to perform testing would turn policy into law-a matter for parliament, not the courts-the ramifications of which would be potentially too far reaching. Of the five judges only Chief Justice Keane would have authorised intervention in the final analysis. It was his view that the plaintiffs had discharged their onus of establishing that the child's constitutional rights could only be upheld by carrying out the PKU test. This he saw as the overcoming of a hurdle that is sufficiently stringent to demonstrate respect for the family while at the same time discharging the state responsibility towards the child himself. As to the matter of setting an unacceptable precedent, he did not consider that the case would pave the way for unwarranted state intervention in family life, since on its facts it was an example of a plea to respect unsubstantiated parental wishes in the face of compelling and uncontested medical evidence and in the absence of a robust defence of religious faith. Accordingly, the way was left open in future cases for parents to challenge medical authority and/or to offer sound reasons why their wishes should be respected.

\section{THE AUTHORITY OF THE COURT TO INTERVENE}

The framing of the legal question in this case was all important to its outcome. These were not wardship proceedings, that is, there was no question that the child should be removed from his family; nor was it a custody dispute where "the family" view-as determined by the parents-would clearly be at odds. ${ }^{3}$ Rather, the case involved a constitutional matter, and as such it had a profound effect on the court's jurisdictional powers.

Importantly, the presumption that flows from the unique constitutional position of the family-namely, that a child's best interests are best determined 
by the family itself -is not one that "parents are always correct according to some objective criterion". Thus, the test for determining the child's best interests is not an objective "responsible parent" test, such as would be applied by a tribunal in wardship or custody proceedings. Indeed, the ill-advisedness of the parental decision was readily commented upon by the Supreme Court. Nor is it simply a question of the child's best medical interests. In fact, no party disputed that these would be served by carrying out an analysis for PKU. It is, rather, a constitutional test, which requires the weighing of all factors to determine the child's best interests, including the role of parental rights in this respect and the child's interest in being part of his family.

\section{DETERMINING BEST INTERESTS}

On one analysis this decision represents a triumph for the view that the best interests test does not simply mean best medical interests-a lesson that the British courts have been slow to learn. It is rightly a matter of best overall interests, although the case also demonstrates all too well that this still leaves the thorny matter of who decides these interests and how. In Ireland, the parents decide, ostensibly by reference to any matter they see fit. For, even though no religious or scientific challenge was proffered in Paul's case to support his parents' objection they were deemed to be well within their rights to object none the less. Parental authority is, accordingly, exceptionally broad. Indeed, as Murphy J put it, there must be a "virtual abdication" of responsibilities or disastrous consequences for the child which are immediate and inevitable before there will be grounds to challenge parental autonomy.

A troubling aspect of the case is, however, precisely its focus on parental rights-being negative rights against the world in general ${ }^{4}$-rather than the question of parental responsibilities towards their children. For example, the ruling makes it clear that there is no obligation necessarily to act in a child's best interests. Instead, it would seem, the obligation is not to act manifestly against those interests, and this is a very different kind of duty. It can be contrasted with the position in the United Kingdom, where the limits of parental authority are firmly set around the concept of acting in a child's best interests. Any conduct which is not within these parameters is outside the authority of parents, and, for that matter, the courts. A much lower threshold is established in Ireland-parents can act howsoever they wish towards their children so long as it is not manifestly against the child's interests.
Despite this, the court's insistence that the essential issue was the paramountcy of the child's welfare sets up a conflict paradigm which it ultimately fails to resolve. If this is truly the kernel of the matter then it is a question of the limits of the respective rights and duties of parents and the state towards children within a family, balanced against the rights of the child as an individual in his own right and as a member of the family itself. While it may be easily accepted that family authority is superior to state authority under the terms of the constitution, this is far less contentious than the protection the constitution accords to family authority as against individual rights.

"The family" - and by this is meant the parents-might be able to speak to the issue of what is right for the unit and its members as a collective, but can they also do so for their children in their capacity as individual citizens of the state? Undeniably, it is part of a child's constitutional rights to be with his or her family, but this ruling says very little about what should happen when the child's constitutional rights as an individual-assessed objectively, medically, rationally, or otherwisepotentially conflict with the family's assessment of them. Interestingly, the majority of judges do not even contemplate this issue.

While in many respects the decision is in keeping with established Irish jurisprudence on the protection of the unfettered exercise of family authority, the point remains that the protection of that authority is not always, or necessarily, in the ultimate best interests of the child. For example, in one case the Supreme Court was prepared to remove a child from adoptive parents after six years and to place him with his natural parents who were complete strangers because the latter constituted a "family" under the constitution. ${ }^{5}$ Although this was a custody dispute, and the Supreme Court was quick to dissociate itself from such authorities in the instant case, the net effect of the present ruling is to endorse the same difficult-to-rebut constitutional presumption in favour of an extremely wide ranging concept of parental rights. This stands in stark contrast to rulings in other jurisdictions such as that of the Supreme Court of Canada which has acknowledged that "[a]s society becomes increasingly aware of the fact that the family is often a very dangerous place for children", the need for state authority to intervene in a child's best interests "assumes greater importance". ${ }^{6}$

The Irish courts have been criticised before for "tilt[ing] the legal balance in favour of the autonomy of the family unit to the possible detriment of individual members", and because the "ideo- logical rigidity of Article 41 envisaged by the drafters no longer reflects the social reality of present day Ireland...". ${ }^{7}$ Certainly, from a contemporary Western legal perspective, the present decision may be seen to pay too much regard to the rights of parents, at the expense of striking a more appropriate balance between these, the rights of children, and the equally important concept of parental responsibility.

\section{A CONCERN ABOUT FLOODGATES}

Concern about opening floodgates to unprecedented state interventions in family decision making was also a crucial element of this case. It was pointed out that no Western jurisdiction has made PKU testing compulsory, and that to allow the appeal would effectively do so in Ireland. Moreover, it was contended that this would set a very low threshold for court and state intervention in the future. As Hardiman J said: "it is better to hesitate at the threshold of compulsion, even in its most benevolent form, than to adopt an easy but reductionist utilitarianism whose consequences may be unpredictable".

But it is not the case that this ruling would necessarily lead to compulsory testing. The chief justice offered examples of how different scenarios might raise different legal issues. Arguably, a finding for the plaintiffs would do no more than shift the burden of establishing best interests to parents in cases where there is strong and compelling evidence on the other side that a child's right to be treated in his own best interests would be served by an intervention. This would not have the effect of undermining parental authority completely. Convincing parental argument that a test should not be performed in a particular case might nevertheless lead to respect for their refusal. If the matter is truly one of balance-as the Supreme Court suggests that it is-then someone must be entitled to offer an alternative view of the child's interests in defence of his rights as an individual. Jurisdictional and legal issues aside, is this not a preferable ethical position to adopt?

\section{A HUMAN RIGHTS ANALYSIS?}

Finally, and from the perspective of individual rights, it is important to bear in mind the provisions of the European Convention on Human Rights, which has been signed by Ireland, although not yet incorporated into domestic law. ${ }^{8}$ No mention is made of this instrument by the Supreme Court, but the European Court of Human Rights is the next and only remaining port of call for the plaintiffs in light of the current ruling. Interestingly, while article $8(1)$ of the 
convention guarantees "respect for family life" and so might support Paul's parents in the first instance, article 8(2) makes it clear that this protection is not absolute, and that derogation is permissible in certain instances, including those "necessary in a democratic society ... for the protection of health ... or for the protection of the rights and freedoms of others". ${ }^{8}$ Political convention dictates that a European Court ruling contrary to that of the Supreme Court would undoubtedly result in a change in Irish law.

J Med Ethics 2002;28:136-138

\section{Authors' affiliation}

G Laurie, Faculty of Law, Old College,

University of Edinburgh, South Bridge,

Edinburgh, EH8 9YL, Scotland:

graeme.laurie@ed.ac.uk

\section{REFERENCES AND NOTES}

1 [2001] IESC 70, 8 Nov 2001.

2 See articles 41 and 42 of the constitution (Bunreacht na hÉireann) which were "heavily influenced by papal encyclicals" according to the Report of the Constitution Review Group. Dublin: Stationery Office, 1996.

3 See The State (Bouzagou) v Station Sergeant, Fitzgibbon St. Gorda Station [1985] IR 426.
4 As was said in L v L [1992] 2 IR 77 "protection of the family by Article 41.1.1. or 2 ... deals with the protection of the family from external forces, rather than purporting to create any particular right within the family or to grant to any individual member of the family rights against other members of the family".

5 M v An Bord Uchtála [1977] IR 287

6 B (R) v Children's Aid Society of Metropolitan Toronto et al [1995] 1 SCR $315,433$.

7 See Martin F. The family in the constitution-principle and practice. In: Murphy T, Twomey P, eds. Ireland's evolving constitution (1937-97). Oxford: Hart, 1998: 93-4.

8 European Convention for the Protection of Human Rights and Fundamental Freedoms. Rome: Council of Europe, 1950.

\section{$\mathrm{ECHO}$}

\section{Privileged information?}

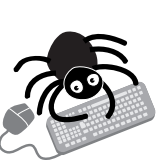

Please visit the Journal of Medica Ethics website [wWw. Imedethics. com] for link to this full article. eaningful research on sports injuries in professionals depends on data being available without
restrictions because of ownership, argues Orchard, in a leading article in the British Journal of Sports
Medicine. public interest and, indeed, the interests of others-among them, sponsors, journalists, and bookmakers-challenging a basic tenet of medicine-the confidentiality surrounding the doctor-patient relationship.

Attempts to conceal information about sports professionals' injuries almost always fail in the face of the vested interests of journalists and bookmakers. And when reasonably accurate data can be found on web sites, should sports injuries research be hampered by having to bow to confidentiality?

Drawbacks to accessing the requisite data responsibly are inevitable-for example, getting agreement from the many stakeholders who may have a claim in a database-but are not insurmountable, as the author's experience with the injury surveillance system of the Australian Football League (AFL) shows. However, researchers must guard against their research being buried forever in consultation processes. Probably the biggest obstacle to accessing such a database for research would be the stance of a university ethics committee, though the author's experience with the AFL does not include this.

When the press routinely use injury data sensationally to sell newsprint it seems counterintuitive for researchers in sports medicine to be unable to use databases for serious studies which would ultimately benefit sports professionals and amateurs alike.

- British Journal of Sports Medicine 2002;36:16-18. 